\title{
THE LIMITS TO DOLLARIZATION IN ECUADOR: LESSONS FROM ARGENTINA
}

\author{
Matias Vernengo \\ Department of Economics \\ University of Utah \\ vernengo@economics.utah.edu \\ Mathew Bradbury \\ Department of Economics \\ City University of new York \\ mathew.bradbury@qc.cuny.edu
}

\begin{abstract}
The paper draws lessons from the failed Argentine experience with convertibility to highlight the dangers of dollarization in Ecuador. Argentina's currency peg to the US dollar was successful in reducing inflation but given the overvalued real exchange rate, created burgeoning twin deficits and a chronic dependency on foreign capital. Ecuador too suffers from chronic current account imbalance. In contrast to Argentina, Ecuador seems to be relying on remittance income to close its external financing gap. Though perhaps this model is less unstable than that of relying on foreign capital it is no more sustainable. The paper closes with a realistic critique of this development strategy.
\end{abstract}

\section{INTRODUCTION}

In January 2000 Ecuador formally adopted the dollar as its currency with the intention of stabilizing the economy. Inflation was high, around 80 percent, and increasing and a balance of payments crisis seemed eminent with a debt-to-exports ratio of 278 percent (Acosta 2001). The drastic measure took place at the same time that the Argentinean experiment with Convertibility a rather less extreme form of dollarization - started to unravel. It is paradoxical, to say the least, that the Ecuadorian authorities did not see the reflection of the future of their country in the Argentinean mirror, so to speak.

As important as the question of why the Ecuadorians opted for a drastic option that would bind their hands for a long period is, we prefer to shed light into the apparent sustainability and success of the dollarization experiment. In fact, dollarization has become an unquestioned pillar of governance in Ecuador, as much as Convertibility was in Argentina, seldom discussed in the literature or in the press, and even those that opposed it, like the current president Rafael Correa, are unable to seriously propose alternatives (Lucas 2007). Yet the basis for the sustainability of dollarization so far has been a significant change in the functioning of the Ecuadorian economy, and the formation of what maybe called a new development model. 
Argentina was able to hold the exchange rate fixed, part of the Convertibility Plan, for more than 10 years fundamentally because international financial markets and the International Monetary Fund (IMF) were willing to finance the increasing current account deficits. In the case of Ecuador, international financial markets have played an insignificant part. The current account in Ecuador is still in surplus, but this results from the large inflows of remittances sent by immigrants. In other words, Ecuador has been increasingly dependent on the exports of its abundant factor of production, namely: labor. This, as we will show, seems to be a flimsy foundation for economic and social progress.

The remainder of the paper is divided in three sections. The following section describes the rise and fall of the Argentinean Convertibility experiment, as a comparative and cautionary tale for Ecuador. The next section describes the main differences and similarities of the current Ecuadorian experience with the Argentinean case. The idea of comparative political economy is to provide "thick descriptions" about how diverse economies respond to rather similar policy experiments and offer lessons about ongoing institutional change. ${ }^{1}$ The last section draws some policy lessons for Ecuador.

\section{THE ARGENTINE MIRROR}

Argentina was one of many emerging market economies to adopt the neoliberal reforms of the Washington Consensus after the stagnant growth and financial turmoil of the 1980s. For Argentina, like for so many countries during the 1990s, these reforms failed to provide sustainable growth, led to financial fragility, and ushered in a new wave of financial volatility and economic crisis.

Argentina began implementing structural reforms in the late $80 \mathrm{~s}$, moving toward more market friendly economic policies. In 1989, barriers to capital mobility were removed and Argentina began a campaign of privatizations. The early 1990s saw the creation of the MERCOSUR regional free trade agreement that included Brazil, Paraguay and Uruguay.

Possibly the most significant threat to threat to the liberalization of the economy was hyperinflation that Argentina had experienced throughout the 1980s. Price instability injects uncertainty into international transactions creating additional costs and frictions to the movement of goods and capital. Hyperinflation would require steady depreciation of the nominal exchange rate to maintain a topside balance of trade. This depreciation would be expected to widen spreads rendering access to foreign investment capital scarce and expensive. Each of these effects does not bode well for an open economy growth model that relies upon foreign consumption and foreign savings to perform. Argentina proceeded with monetary reforms designed to create a stable price environment.

In 1991, a fixed exchange rate was adopted which pegged the pesos one-to-one to the U.S. dollar. Known as the Convertibility Plan, the fixed peg was designed to constrain monetary policy, lending credibility to monetary policy through utilizing the exchange rate as a nominal anchor for inflation.

\footnotetext{
${ }^{1}$ For the comparative political economy methodology and its relation to comparative anthropological studies see Taylor (2006).
} 
The success of the Convertibility Plan in taming inflation was expedient and dramatic. (Figure 1). The remarkable performance of the policy led the IMF to tout Argentina as the poster-child of structural reforms. But, the characteristics of the monetary reform from which convertibility derived its impressive success in taming inflation were exactly those that would ultimately lead to its collapse. ${ }^{2}$

Figure 1. Argentina Inflation, 1992-2001. (CPI, Annual \%)

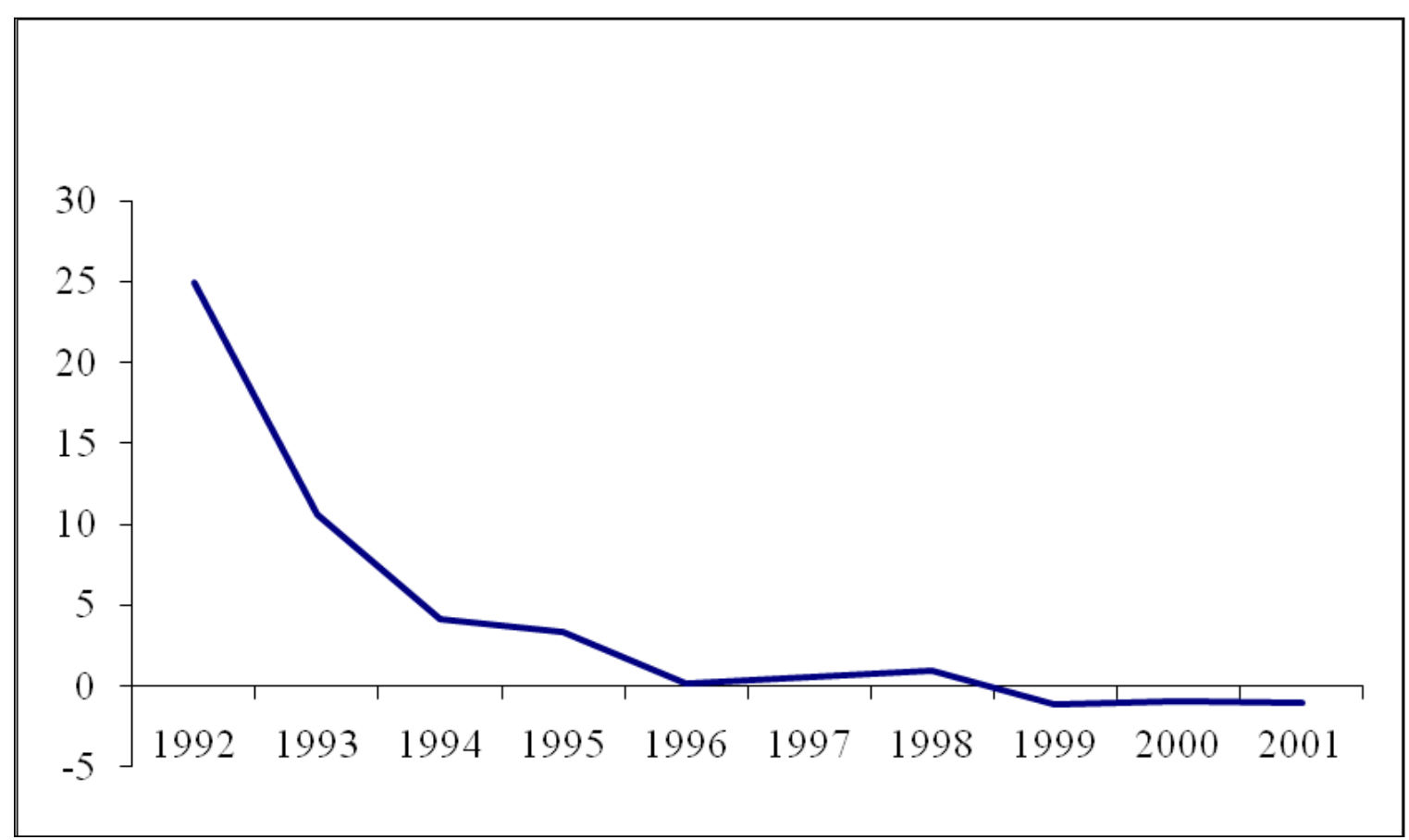

Source: World Bank (2008a).

The Convertibility Plan was undertaken both to facilitate increased trade openness and to entice waves of capital flows. It was presumed that these reforms would amplify growth. However, the fixed exchange rate was associated with an over-appreciated real exchange rate, which together created conditions necessitating a blooming current account deficit. Furthermore, the rigidities associated with convertibility proved not to amplify growth, but to amplify the negative impact of a series of external economic shocks. Argentina was left with a twin-deficit, current account and fiscal debt, that undermined both debt and currency sustainability. These weaknesses ultimately led to the collapse of the regime in December 2001 and a major default on much of the public debt in February 2002.

\footnotetext{
2 However, the success should not be read as a justification for the conventional interpretation of hyperinflationary processes. A fixed peg allowed the price of imported goods and of all tradables to stabilize immediately, and for a slow adjustment of non-tradables to international prices. For a discussion of alternative theories of inflation see Vernengo (2006).
} 
A fixed exchange rate is effectively bilateral currency union. The logic of optimal currency unions specify that if the currencies of countries are to be tied, these countries should share similar rates of productivity growth, face similar business cycles, or have a unified labor market. In the case of Argentina and the United States, these favorable preconditions for convertibility were not met.

During the 1990s the U.S. experienced an economic boom, and productivity growth that greatly exceeded that of Argentina. The U.S. dollar appreciated throughout the 1990s, which implied appreciation of the peso, reducing competitiveness for Argentina in export markets. A rising dollar and strong U.S. productivity growth provided for the appreciation of Argentina's real exchange rate, which was overvalued from the beginning of the Convertibility Plan. This trend in the real exchange rate explains the chronic external imbalance during the 1990s during which Argentina ran consistent current account deficits (Figure 2).

The accumulation of debt implied by the current account deficit was augmented by deficits in the fiscal balance as well. Though the Argentine government was able to run primary fiscal surpluses through most of the 1990s, once interest payments were taken into account, the overall fiscal balance registered deficits (Table 1). The magnitude of the overall deficits was partly masked by windfall gains from privatizations. These interest payments became the main expenditure and the major problem for the country (Schvarzer 2002). ${ }^{3}$

Figure 2. Argentina Current Account, 1992-2002 (US Millions).

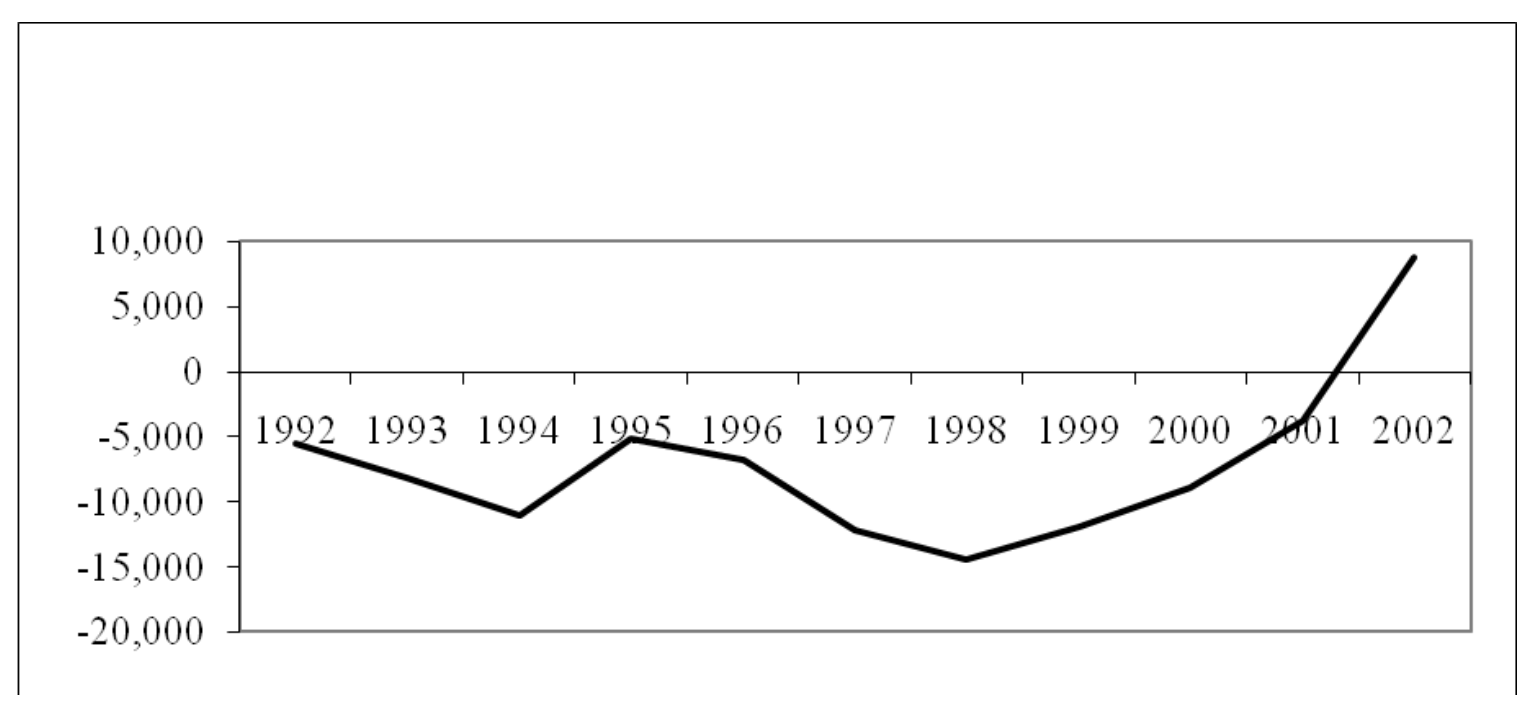

Source: INDEC Republic of Argentina.

Immediately after the crisis many had argued that the fixed exchange rated and structural adjustment toward rapid capital market liberalization was not a fundamental cause of the

${ }^{3}$ Interest payments depended on credit rating process of international agencies (Standard \& Poor's and Moody's). The current account deterioration led to a worsening of the credit standing, a higher risk premium and higher interest payments. Hence, increasingly higher primary surpluses were necessary to maintain fiscal balance. See Damill, Frenkel, and Juvenal (2003). 


\section{JOURNAL OF WORLD-SYSTEMS RESEARCH}

Argentine crisis. In the same breath, fiscal profligacy had been highlighted as the main policy foible that created the crisis prone structure (IMF 2004; Mussa 2002). But a reading of the fiscal accounts reveals this argument to be untenable. Fiscal spending was not excessive, in fact, a swath of contractionary fiscal spending measures had been adopted in the late 1990s and spending as a share of GDP remained relatively flat through these years. The source of Argentina's fiscal deficits was not a policy choice but a consequence of the structure of the debt. ${ }^{4}$

Table 1. Argentina Fiscal Balance 1997-2003 (Millions of Pesos)

\begin{tabular}{lcrrrrrr}
\hline & 1997 & 1998 & 1999 & 2000 & 2001 & 2002 & 2003 \\
\hline Primary Fiscal & & & & & & & \\
$\quad$ Balance & 1162.7 & 2490.5 & 876.1 & 2720.0 & 1395.0 & 2256.0 & 8677.0 \\
Interest Payments & 5745.0 & 6660.3 & 8223.6 & 9656.0 & 10175.0 & 6810.0 & 6883.0 \\
Privatization & & & & & & & \\
$\quad$ Proceeds & 305.7 & 96.3 & 2579.1 & 145.0 & 60.0 & 5.0 & 11.0 \\
Overall Balance & -4276.6 & -4073.5 & -4768.4 & 6792.0 & 8719.0 & 4549.0 & 1805.0 \\
\hline
\end{tabular}

Source: Ministry of the Economy and Production.

Argentina's twin-deficits spelled out a debt trap that, coupled with the nature of the exchange rate regime, revealed an unsustainable dependency of foreign capital that would ultimately lead to exploding debt and collapse of the exchange rate regime. The external imbalance and overall structural tendency toward accumulation of debt was aggravated by a series of external shocks that hit the economy starting in the late 1990s. At their root these shocks were primarily related to volatility in global financial markets.

In 1999, Brazil was forced to devalue its currency. As Brazil was both a key trading partner and key competitor in European export markets, the devaluation represented deterioration in Argentina's competitiveness, worsening the tendency toward current account deficits. With the nominal exchange rate fixed, adjustment began to take the form of economic recession. The growth rate of GDP fell from 8.1\% to 3.9\% moving into 1998 and by 1999 growth was negative at $-3.4 \%$, (Table 2 ).

The Brazilian devaluation was primarily a response to financial turmoil in global capital markets. Financial crisis in East Asia in 1997 had not been localized to the region. In 1998, the crisis had spread to force payments crisis in Russia and Brazil. This contagion of crisis transmitted through financial markets to impact Argentina not only indirectly, through Brazil's devaluation, but directly as international investors became more risk averse, international capital markets constricted and risk premiums increased making new debt more scarce and more expensive.

Argentina was left in a squeeze in which adverse shocks to the trade balance and rising fiscal deficits necessitated increased foreign borrowing just at the time when it was becoming more burdensome. For this reason the depth of Argentina's debt trap was amplified by adverse external financial conditions.

\footnotetext{
${ }^{4}$ For work highlighting this type of endogenous fiscal deterioration see, Vernengo (2006).
} 
LIMITS TO DOLLARIZATION 452

Table 2. Argentina Sustainability Indicators (1997-2001)

\begin{tabular}{lrrrrr}
\hline & 1997 & 1998 & 1999 & 2000 & 2001 \\
\hline GDP Growth\% & 8.1 & 3.9 & -3.4 & -0.8 & -4.4 \\
Total Debt to GDP\% & 34.8 & 37.5 & 42.9 & 45.0 & 53.8 \\
Total Debt Service to Reserves \% & 81.5 & 86.7 & 97.7 & 108.6 & 107.4 \\
Total Debt Service to Exports \% & 49.8 & 57.3 & 75.1 & 70.5 & 42.6 \\
External Debt to Exports \% & 413 & 452 & 519.7 & 471.3 & 494.2 \\
\hline
\end{tabular}

Source: World Bank (2008b).

Both sides of the twin deficit were affected. The current account deficit was aggravated by rising net interest payments and Brazil's devaluation. The overall fiscal deficit was aggravated by spectacular rise in the government's debt service burden. As the recession deepened and debt continued to spiral out of control, sustainability indicators for the government debt deteriorated. This trend increasingly provoked the notion that the country would be unable to mitigate pressures on the nominal exchange rate and would ultimately be forced to devalue.

An unfortunate consequence of the emergence of questions regarding the sustainability of the exchange rate was the reemergence of exchange rate risk. The early success of convertibility had created the perception that exchange rate risk had been reduced or eliminated. As a consequence of convertibility there was an explosion of foreign borrowing by the private sector. This trend represents a de-facto dollarization of the liability structure of the economy as a whole. Under favorable conditions there is no obvious problem, but the reemergence of exchange rate risk revealed another underlying fragility of the financial system, taking the form of widespread balance sheet mismatches (Taylor 1998).

These worsening trends in sustainability could only reinforce the pessimistic sentiments of risk adverse investors thereby perpetuating the financial shocks that had deepened Argentina's debt trap, further leveraging the economy toward crisis. Details of the rules governing the Convertibility Plan go above and beyond the accumulation of debt in highlighting three key elements of the crisis: (i) the dependency on foreign capital, (ii) the centrality of fiscal sustainability in maintaining the ability of the authorities to defend the peg, and (iii) the way in which both fiscal and monetary policy were dictated by international capital movements each responding to adverse external shocks by forcing further contraction of the economy.

In fixing rate of exchange between the peso and the dollar the Convertibility Plan required that the central bank maintained levels of international reserves at least equal to the monetary base. This constrained monetary policy because to combat an economic downturn the money supply could only be increased if additional international reserves were both available and exceeded the monetary base. Interest rates had to remain high to attract capital flows.

It should be noted that the Convertibility Plan did allow for some latitude since a third of these international reserves could take the form of bonds issued by the Argentine government and denominated in U.S. Dollars. However, even this latitude was constrained as the convertibility 
law dictated that reserves in the form of dollar-denominated Argentine government bonds could not increase more than $10 \%$ per year.

Additional tools available to the central bank were reserve requirements on deposits of various terms. Manipulation of these reserve requirements would be a prominent feature of monetary policy efforts to manage liquidity in the years of the 1990s as the country proceeded toward crisis. The central bank could act in limited fashion as a lender of last resort providing credit to the banking system, but only on a short term basis. The central bank could provide credit to the government in a limited fashion and only indirectly thought he purchase of government securities. The central bank retained the power to regulate required bank reserves. Later, in response to the pressures brought about by the Mexican devaluation and Tequila crisis of 1995 more latitude was given to the central bank to act as a lender of last resort. This latitude was provided when the central bank was allowed to incur foreign indebtedness and conduct repo agreements with large international banks in order to provide short-term loans to the domestic financial system (Prospectus 2004).

With the hands of monetary policy tied to the availability of foreign capital, fiscal policy was left as the primary tool for stabilization of the economy. The fiscal balance was central in another regard as well. The sustainability of the currency regime depended critically on access to international reserves. If these were not forthcoming from trade they would need to be acquired from international capital markets and the sustainability of the fiscal balance determined the ability of the government to access these markets. If the debt of the government was suspect so to would be the sustainability of the currency regime.

The wave of external shocks that hit the Argentine economy in the late 1990s created pressure on the sustainability of the peg because they exacerbated external imbalances, but at the same time these shocks generated an endogenous deterioration of the overall fiscal balance and fiscal sustainability. Dependency on foreign capital which was needed to service twin deficits in defense of the peg dictated that capital flows be called forth at a time when capital markets were retrenching and Argentina's internal conditions were deteriorating. These conditions and the direction of risk premiums necessitated rising interest rates and implementation of contractionary fiscal policy in the hopes of compensating for investor's fears regarding the overall economy and in calling forth adequate capital flows.

The initial retrenchment in capital flows that began in 1998 became a reversal by 2000 throughout this interval the central bank was forced to intervene in defense of the currency. As international capital markets contracted, and this contraction was reinforce by endogenous deterioration of fundamentals within the Argentine economy monetary policy too was forced into a contractionary stance. A view of liquidity aggregates shows the squeeze in narrow money as conditions deteriorate, Table 3 ).

The initial reduction in the currency, M1 and M2 from 1999 through 2001 reflects two trends. First, the reduction in net capital inflows from which the reserves required to back the monetary base were acquired. Second, a flight to quality as deposits shifted from shorter-term peso-denominated deposits to longer-term dollar-denominated deposits. This latter trend provides for the increase in M3 through 2001. The collapse of broad money in 2002 reflects capital flight as even dollar deposits began to be moved off shore. 
Table 3. Argentina Liquidity Aggregates 1999-2002

\begin{tabular}{lrrrr}
\hline & 1999 & 2000 & 2001 & 2002 \\
\hline Currency & 1.7 & -8.5 & -27.7 & 80.8 \\
M1 & -3.9 & -3.2 & -28.4 & 94.8 \\
M2 & -4.7 & -3 & -31.8 & 96 \\
M3 & 2.3 & 4.3 & 23 & 13.3 \\
Monetary Base & 0.8 & -8.7 & -21 & 145.1 \\
\hline
\end{tabular}

Source: Ministry of Economy and Production.

This contraction triggered a traditional debt deflation in the economy further exposing fragility of firms' balance sheets. Argentina had utilized what tools it had available in an attempt to turn the tide against the collapse of the money supply. But a pronounced deflationary trend could not be avoided. Thus both fiscal and monetary policies were forced into a contractionary stance during the recession of the late 1990s. Not only was the nature of fiscal and monetary policies incapable of counteracting the negative external shocks that hit the economy in the late 1990s, these shocks were amplified by concerted policy contraction. Argentina had not given over monetary policy to the Federal Reserve of the U.S. It had given control of the money supply to the vacillations of agents in international capital markets. Both monetary and fiscal macroeconomic policy had become pro-cyclical, aggravating the economic downturn.

Throughout the contraction in the monetary base the central bank struggled within the rules of convertibility to provide liquidity to the financial system. The central bank was being squeezed between attempting to provide liquidity to the financial system and defending the currency. The primary tool used was adjustment to the required reserves on bank deposits. Throughout 2001 the central bank began lowering reserve requirements on term deposits and eliminated reserve requirements on short-term deposits. Depending on the maturity, reserve requirements were lowered from a range of $10-22 \%$ to a range of $3-15 \%$. Reserve requirements were raised on demand deposits from $15.5 \%$ to $18.4 \%$. In an attempt to repatriate funds the limit of reserves that could be maintained outside the country was reduced. In an additional attempt to provide liquidity to the financial system the central bank began paying interest on required reserves. The central bank allowed financial institutions to meet their reserve requirements in the form of government bonds (Prospectus 2004).

This last measure highlights an important point considering the deteriorating sustainability of the government's debt burden. Many of the measures designed to provide a short-term loosening of the liquidity constraint faced by financial institution might have also contributed to fears regarding their viability. Though this would have reinforced the exodus of capital from the economy, the main driver of this flight was concern over the value of the currency. The deterioration of the banking system was then a consequence of convertibility and measures to correct the weakening of financial institutions could not be successfully undertaken in the presence of convertibility.

Augmenting the fears over the ability of the authorities to defend the currency were fears over sustainability of the government debt. These fears were actualized when in late 2001 the government announced it would suspend payments on a large portion of the public debt. The significant run on deposits continued through 2001 and capital controls were instituted in December of 2001. The Corralito (little corral) froze all dollar and peso-denominated demand 
deposits. Limiting withdrawal to $\$ 250$ per week. Continued capital flight throughout December 2001 forced congress to enact the Public Emergency Law in January of 2002 that terminated the Convertibility Plan. Shortly after, the exchange rate depreciated more than $236 \%$ against the dollar. The Convertibility experiment was over.

\section{IMPORTING CURRENCY AND EXPORTING PEOPLE}

In January 2000 Ecuador became the second Latin American country, after Panama in $1903,{ }^{5}$ to adopt the U.S. dollar as its official currency. ${ }^{6}$ The change was announced by President Jamil Mahuad, which fell after military and indigenous rebellions, ${ }^{7}$ and was confirmed and implemented following the swearing in of the vice-president Gustavo Noboa. In other words, the decision to dollarize was taken in the midst of a severely unstable political situation. Interestingly enough inflation, which was the main economic reason for dollarization, was high $(52.2 \%$ in 1999), but far from a hyperinflationary situation, even though it seemed to be accelerating $(96.1 \%$ in 2000). In that respect it is hard to believe that dollarization was in any technical sense necessary for stabilization, since stable prices had been reached in several Latin American countries without having to resort to such drastic measures (Acosta 2001: 242).

If anything, dollarization seems to have been adopted as an extension of the policies of the liberalization period that started in 1992, and as a result of the deep economic crisis of 1999, when the economy contracted $7.3 \%$ in real terms. In that respect, dollarization, as much as the Convertibility Plan in Argentina, can be seen as the culmination of a long process of restructuring of the economy that started with the debt crisis of 1982.

The 1980s was in Ecuador, as in the rest of Latin America, a lost decade. Average growth of GDP per capita from 1980 to 1989 was $-0.7 \%$, a fall that was larger than the average for the region in the same period. The 1990s brought a complete adherence to the Washington Consensus canon of liberalization, deregulation and privatization. In 1994 Ecuador signed the Brady agreement and restructured its foreign obligations, and together with the market friendly reforms it was expected that the country would move beyond the stagnation of the $1980 \mathrm{~s}$.

The economy, however, continued to stall, and real GDP growth was $1.87 \%$ for the 1990s, below population growth, in particular because of the profound crisis in 1999. Trade liberalization reinforced the inability to move beyond the dependency of oil exports, even though some non-traditional exports were developed (e.g. flowers and fruits other than bananas), implying a extreme vulnerability to changes in the terms of trade. Financial liberalization and deregulation reinforced the process of currency substitution, and the increasing dollarization of the economy, which led to significant amounts of capital flight throughout the 1990s. The dismantling of the public credit system also implied that credit for productive purposes almost vanished.

Meanwhile income distribution variables worsened considerably during the $1990 \mathrm{~s}$. The income of the lowest quintile fell from $4.6 \%$ to $2.46 \%$ of total income, while that of the highest

\footnotetext{
${ }^{5}$ For an account of the separation of Panama from Colombia and the roles of the U.S. government and J.P. Morgan see Díaz-Espino (2001).

${ }^{6}$ A year later El Salvador and Guatemala also formally dollarized their economies.

${ }^{7}$ A discussion of the Ecuadorian indigenous movement can be found in Jameson (2008).
} 
quintile increased from $52 \%$ to $61.2 \%$. In other words, the income of the $20 \%$ poorest in the country was compressed by almost $90 \%$ during the neoliberal period. Poverty also ballooned from $34 \%$ of the population in 1995 to $71 \%$ in 2000, with extreme poverty or indigence increasing from $12 \%$ to $31 \%$ in the same period. By almost any metric the Washington Consensus policies failed to improve the situation of the Ecuadorian people. In 1999, as a result of the fall in the price of oil in international markets, and the productive disruptions caused by the 'El Niño,' the economy collapsed. This is the context in which dollarization was adopted.

In at least one respect dollarization was relatively efficient. As much as in the Argentinean case inflation fell considerably, and converged to international levels. Figure 3 shows the evolution of the consumer price index in the period after dollarization. It is worth noticing that inflation remained in the 2-digit level for a couple of years, leading to a real appreciation of the exchange rate.

In fact, the appreciation of the real exchange rate after dollarization is one of the most important effects of the reform, and often one of the least understood. The general public has difficulty in noticing appreciation, since the exchange rate, once the country dollarizes, disappears. However, the relative cost of domestic goods vis-à-vis foreign goods remains central for the evolution of the current account.

\section{Figure 3. Ecuador Inflation, CPI Annual \% (1991-2007)}

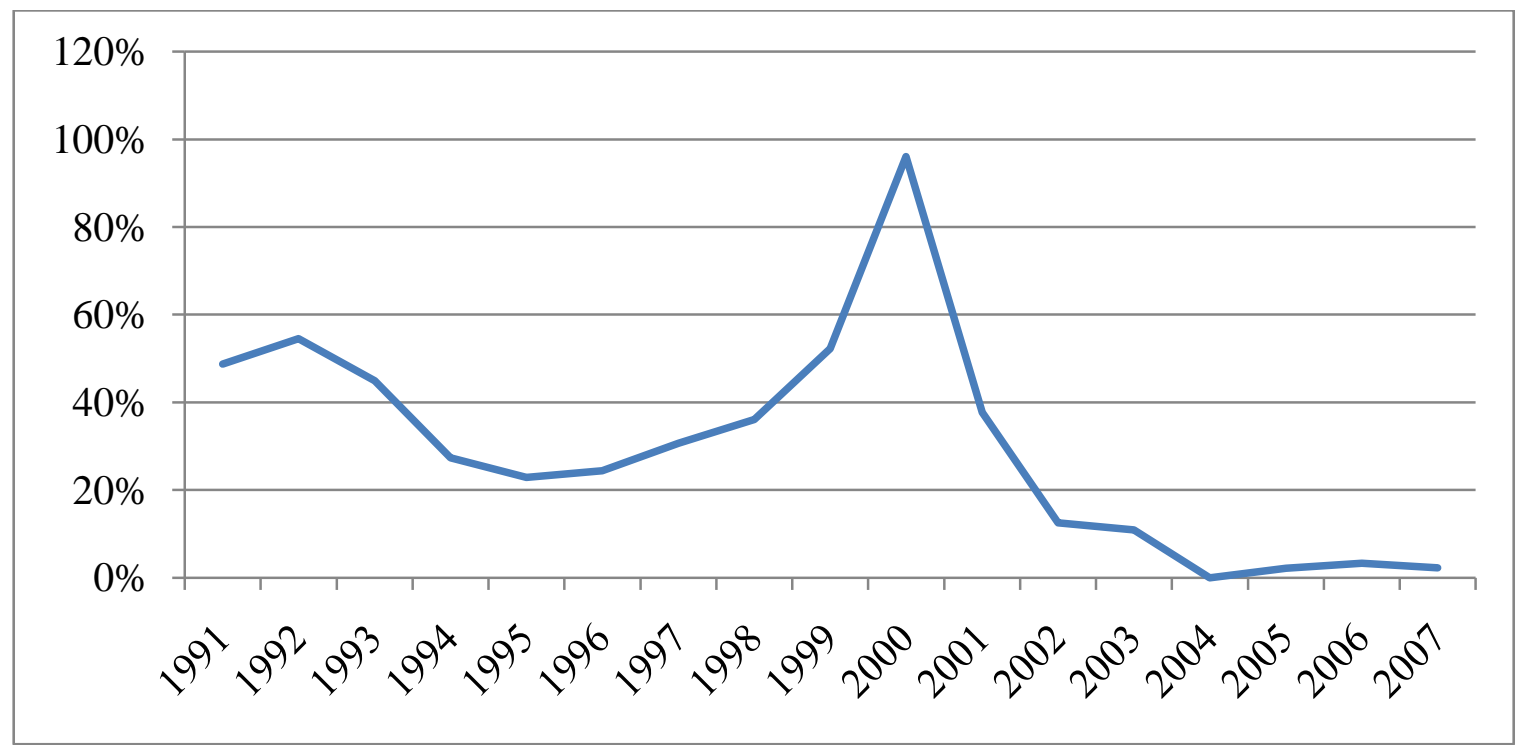

Source: ECLAC (2009).

Figure 4 shows the evolution of the real exchange rate in Argentina, which devalued heavily after the 2001 crisis, and Ecuador. The scale of the Argentinean depreciation dwarfs the Ecuadorian appreciation, but the effects should not be minimized. A significant appreciation of the currency compounds the effects of the liberalization of the trade and capital accounts of the 1990s, making it difficult for Ecuador to manage its balance of payments disequilibria. 
In the absence of vigorous increases in labor productivity the only other alternative for a country to increase its external competitiveness is by depreciating its exchange rate. A dollarized economy, by definition, eliminated the second alternative as a policy instrument.

Figure 4 -Argentina and Ecuador, Real Exchange Rate (2000-2008)

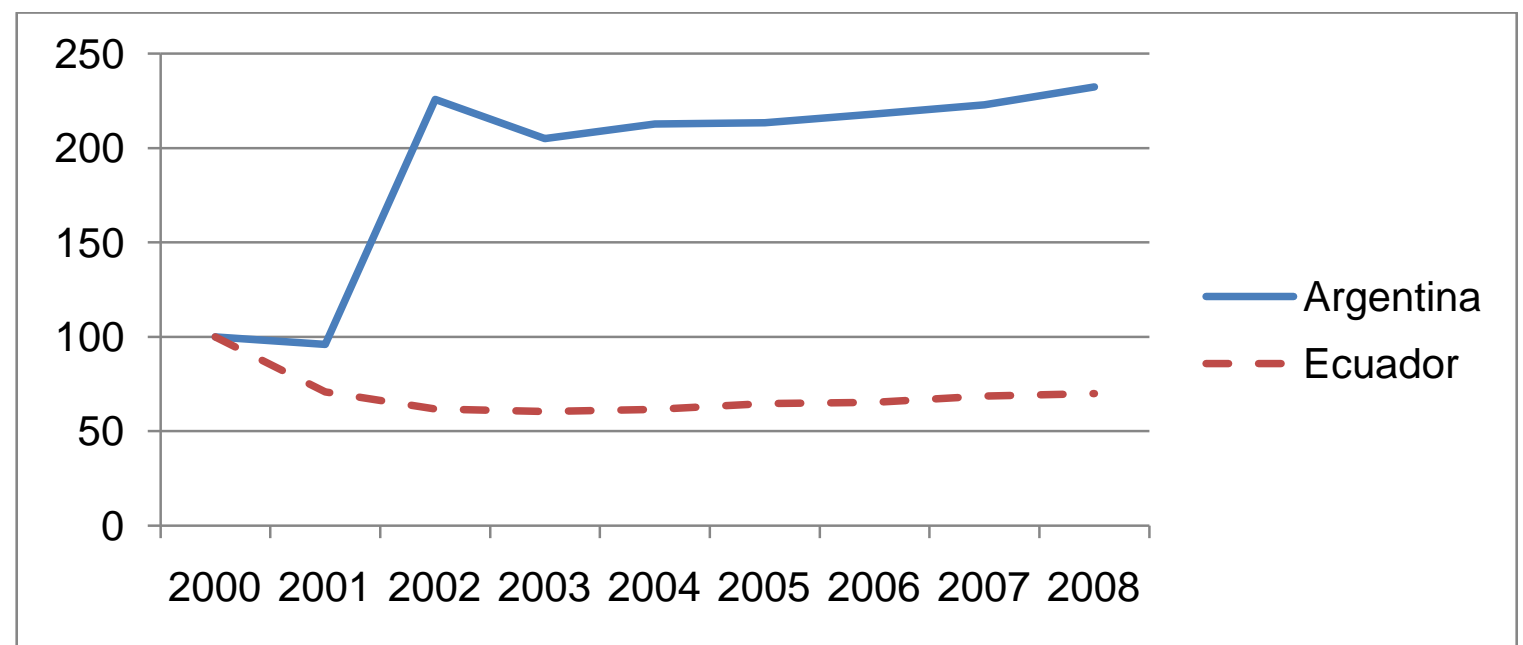

Note: Year 2000 $=100$, Deflated by CPI

Source: ECLAC (2009).

The Ecuadorian case shows that, in fact, the situation could be worse, since the relative changes of domestic and foreign prices, exogenously, determined the competitiveness of the country. Ecuador, we may note, has been comparatively lucky, since it dollarized in a period that the dollar has lost around 30\% of its value against other currencies, boosting Ecuadorian exports in the process. Also, since 2002 the prices of commodities, oil in particular, had boomed. All of these international conditions have eased the Ecuadorian external constraint. By contrast, the 1990s were marked by the appreciation of the dollar and falling commodity prices, which actually made the Argentinean Convertibility less manageable.

These differences between the Argentinean and Ecuadorian experience explain why Argentina had to rely on international financial markets, and recurring loans from the IMF in order to maintain convertibility, and Ecuador, after the election of Correa, could decisively break with the multilateral institutions, and promote an audit of the external debt with a view of not paying it in full, something that in Argentina was only possible after the default in 2002.

However, it would be a mistake to think that the commodity boom and dollar depreciation have given Ecuador sufficient space in their balance of payments to grow with encountering any kind of restrictions. In fact, as Figure 5 shows the current account has only recently switched to surplus, after having been in deficit for all of the 1980s and 1990s, and a good part of this century. Yet, this is not the most disconcerting fact to emerge from Figure 5. In fact, if we remove remittances, sent by Ecuadorian living abroad, the current account would still be in deficit, even though the growth performance has been so far dismal, with one of the lowest rates of per capita growth in the region. 
Remittances have been increasingly relevant for Latin America. In part, the flow of remittances may be explained by the good performance of developed countries in the period 2002-2006. However, most analyses indicate that the significant rise in remittances is explained by the rising flow of immigration (legal and illegal), in the case of Ecuador to Spain and the United States. It is important to note that immigrants tend to be working age adults, and to be relatively educated. For example, in the case of Ecuador $20 \%$ of the labor force emigrated, and of those $64 \%$ of the males and $73 \%$ of the females have at least secondary education (FLACSO 2006). In the case of Latin America as remittances can represent between $50 \%$ and $80 \%$ of recipient income, they can constitute an important tool for improving infrastructure, raising educational levels and financing productive activities.

Figure 5. Current Account with and without Remittances (1989-2008)

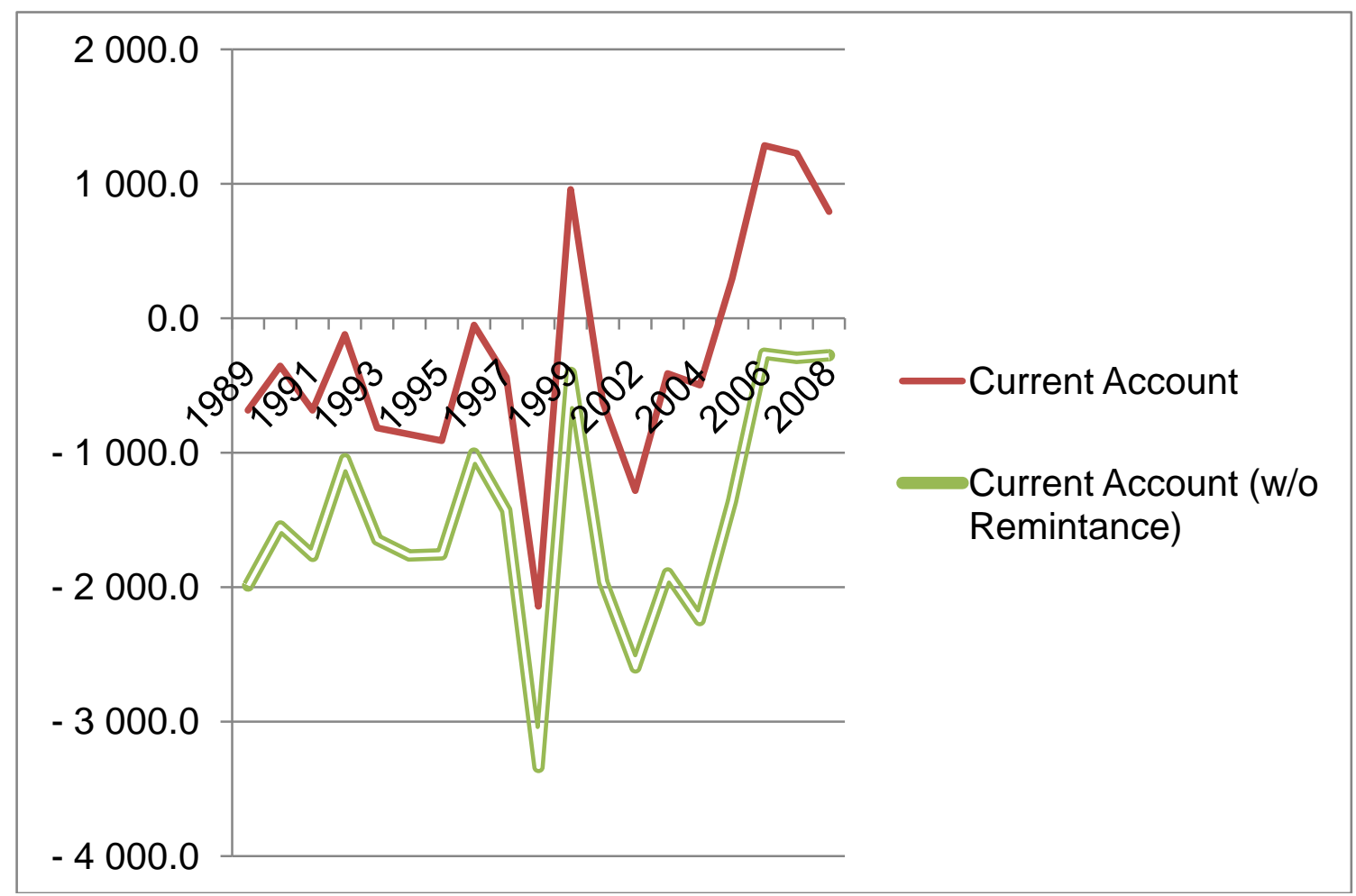

Source: ECLAC (2009).

However, the evidence suggests that the vast majority of remittances are used for everyday consumption. In the case of Ecuador, $70 \%$ and $75 \%$ of the remittances sent by males and females respectively are used to buy food, pay rent and for other domestic expenses, with only $12 \%$ and $7 \%$ for health expenses (FLACSO 2006). The amount used for investment and education is negligible.

The most important aspect of remittances for Ecuador is that of narrowing in the short and perhaps medium run the external financing gap. At the aggregate level for Latin America remittances have managed to narrow the current account gap by $0.56 \%, 0.91 \%$ and $1.9 \%$ 
percentage point of GDP between 1980-1990; 1991-2001 and 2002-2006 respectively. More to the point, had it not been for the increased flow of remittances in the period 2002-2006, Latin America's current account would not have been in surplus. Rather, when the current account adjusted for remittances, its result is negative and of the order of $-1.1 \%$ of regional GDP. Table 4 shows the contributions of remittances in Argentina and Ecuador since 1980 to the closing of the financial gap.

It is clear from the Table 4 than in Ecuador remittances always played a more important role than in Argentina. Further, whereas in the 1980s, remittances only contributed to $0.6 \%$ of current account to GDP funds, the figure increased to $3.5 \%$ in the $1990 \mathrm{~s}$ and to an impressive $6.46 \%$ in the dollarization period. In other words, the transition to the neoliberal period that started with the debt crisis, passed through the adoption of the Washington Consensus in the 1990 s, and culminated with dollarization in this century, seems to be increasingly dependent upon the remittances sent by immigrants.

\begin{tabular}{|c|c|c|c|}
\hline & $1980-90$ & 1990-2001 & $2001-2006$ \\
\hline \multicolumn{4}{|l|}{ Argentina } \\
\hline Current Account & -2.52 & -2.98 & 4.83 \\
\hline CA Adjusted for Remittances & -2.59 & -3.19 & 4.44 \\
\hline Contributions of Remittances & 0.07 & 0.22 & 0.38 \\
\hline \multicolumn{4}{|l|}{ Ecuador } \\
\hline Current Account & -5.58 & -2.32 & -1.31 \\
\hline CA Adjusted for Remittances & -6.19 & -5.83 & -7.77 \\
\hline Contributions of Remittances & 0.60 & 3.50 & 6.46 \\
\hline
\end{tabular}

Source: World Bank (2008).

This suggests that the sustainability of dollarization in Ecuador, in contrast to Argentina that has never depended heavily on remittances as shown in Table 4, is based not on the old Commodity-Export Model, but on a new Anthropo-Export Model, so to speak, which depends increasingly on its ability to export what seems to be its most competitive product, namely: its own people.

Also, it is important to emphasize that dollarization and immigration are symbiotically interconnected in the new development strategy. Dollarization and financial openness have allowed greater integration of Ecuador into international financial markets, and in that respect accumulation is not a national phenomenon anymore. The economic elites of Guayaquil are internationalized and their reserves are maintained in dollars, but that is only possible because of the permanent outflows of Ecuadorians to foreign countries. ${ }^{8}$ Arguably, the new development strategy is tearing apart the very elements that used to constitute the national economy, that is,

\footnotetext{
${ }^{8}$ A similar development strategy, in which economic group acquire a financial logic while increase the dependence on remittances, seemed to have taken place in Central America. For the cases of El Salvador and Guatemala see Segovia (2002) and Gammage (2006).
} 
that accumulation was based in productive circles within the national territory, and that, as a result, workers could find jobs in the national economy.

Yet, there are significant problems with the new development strategy in Ecuador, which suggest that dollarization is ultimately untenable and will, as much as the Convertibility Plan in Argentina, collapse in due time. The most obvious is the fact that the immigration process depends on the willingness of foreign countries, in particular Spain and the United States, to, by legal means or by indifference towards illegal immigrants, accept a permanent flow of people into their economies. This seems to be increasingly unacceptable, and a severe backlash against immigration in the developed world seems to be indicating the proximity of the limits to the current development strategy.

In addition, the fact that the most qualified part of the labor force is the one that is being exported suggests that the effects on the domestic economy will be significantly greater than the reduction of labor supply. The quality of the labor input is worsening, and as a result labor productivity is impacted with long-term effects on development.

\section{BEYOND DOLLARIZATION}

In our view, the limits of the current development strategy based on exporting people will eventually lead to persistent and unsustainable current account deficits, economic contraction (to reduce imports) and eventually forced devaluation, which in Ecuador's case implies sucretization. $^{9}$ As bad as that scenario bodes for the future of the country, it is worth noticing that the Argentinean debacle of 2001/2 has led way to a sustained recovery, and that rather then waiting for the inevitable the Ecuadorian authorities could take measures to minimize the costs of the sucretization process.

The first measure that is relatively simple to operationalize is to recover fiscal policy as an instrument of anti-cyclical management. Since dollarization Ecuador has maintained primary surpluses and nominal deficits, as much as the rest of the region. In 2006, the primary surplus was of the order of $2.1 \%$ of GDP, while the nominal deficit was $0.2 \%$, that is, the difference between the two, which corresponds to interest payments, and are $2.3 \%$ of GDP, go to bond holders. A compression of interest payments, and an increase of spending in infrastructure, and social programs (to qualify the labor force, for example), would create jobs and promote development in the short-run, while diminishing the possible effects of a forced sucretization in the future, since with the new jobs and skills less workers would be dependent on foreign remittances.

Also, even though sucretization is not, and most likely will not be in the near future, part of the political agenda, partial de-dollarization (reverse currency substitution) is possible and should be pursued. A simple idea is to allow a locally issued token to be used for tax payments. Locally established firms and private agents will be reassured that the token is accepted by the government for tax payments, and will most likely want to economize in their use of foreign currency. This would stimulate the circulation of the local token for domestic (non-tradable) transactions. The maximum amount that can be printed would be the limit of the tax revenue, which would be considerably higher than what is needed for recovering the loss of seigniorage

\footnotetext{
${ }^{9}$ For an early warning of the limits of dollarization in Ecuador see Vernengo (2001).
} 
with dollarization (somewhere around 2 or $3 \%$ of GDP). This, in turn, will allow a certain amount of discretionarity in monetary policy matters.

Recovering fiscal and monetary policy should be the first steps to create more degrees of freedom for domestic policy makers, which would give them the tools necessary to smooth out the possible collapse of the current development strategy. It seems that the administration of Rafael Correa is eager about trying new alternatives, and that suggests that at least there is a hope that the Ecuadorian story will have a happier ending than the Argentinean Convertibility Plan. Hope springs eternal!

\section{ACKNOWLEDGEMENTS}

We thank, without implicating, comments by conference participants, and several conversations on the Ecuadorian case with Fander Falconí, Ken Jameson, Pedro Páez, Esteban Pérez and Juan Ponce.

\section{REFERENCES}

Acosta, A. 2001. Breve Historia Económica del Ecuador. Quito: Corporación Editora Nacional, 2a Edición, 2006.

Damill, M., R. Frenkel, and L. Juvenal. 2003. "Las Cuentas Públicas y la Crisis de la Convertibilidad en la Argentina," Desarrollo Económico, 43(170), Jul.-Set., pp. 203229.

Díaz-Espino, O. 2001. How Wall Street Created a Nation. New York: Basic Books.

ECLAC. 2007. Estudio Económico de América Latina y el Caribe, 2006-2007. Santiago, Chile.

FLACSO. 2006. Ecuador: Las cifras de la migración internacional. Quito, Ecuador.

Gammage, S. 2006. "Exporting People and Recruiting Remittances: A Development Strategy for El Salvador?" Latin American Perspectives, 33(6):75-100.

IMF. 2004. "The IMF and Argentina 1991-2001". IEO Evaluation Report

Jameson, K. 2008. "The Indigenous Movement and the Economic Trajectory of Ecuador." University of Utah, Working Paper No. 2008/05.

Lucas, K. 2007. Rafael Correa: Un Extraño en Carandolet. Quito: Sudamericana.

Mussa, M. 2002. Argentina and the Fund: From triumph to tragedy. Washington Institute For International Economics.

Prospectus. 2004. The Republic of Argentina: Debt securities, Warrants, Units. Amendment no. 3 to the registration statement under schedule b of the Securities Act of 1933. Securities and Exchange Commission. Registration no. 333-117111.

Schvarzer, J. 2002. Convertibilidad y Deuda Externa. Buenos Aires: Eudeba, 2003.

Segovia, A. 2002. Transformación Estructural y Reforma Económica en El Salvador. Guatemala: F\&G Editores.

Taylor, L. 1998. "Lax Public Sector, Destabilizing Private Sector: Origins of Capital Market Crises," SCEPA Working Paper, No.1998-11. 
Taylor, L. 2006. "External Liberalization in Asia, Post-Socialist Europe, and Brazil." In L. Taylor, (ed.), External Liberalization In Asia, Post-Socialist Europe, and Brazil. New York: Oxford University Press.

Vernengo, M. 2001. "Es la depreciación suficiente? Liberalización externa en Brasil y lecciones para Ecuador," Cuestiones Económicas, 17(1), Quito, Banco Central del Ecuador.

Vernengo, M. 2006. "Globalization and Endogenous Fiscal Crisis." In P. Berglund and M. Vernengo. (eds.) The Means to Prosperity: Fiscal policy reconsidered. London Routledge.

World Bank. 2008a. World Bank Development Indicators. Washington., D.C.

World Bank. 2008b. Global Finance Indicators. Washington., D.C. 